\title{
Follow-up of patients with mycosis fungoides after interferon $\alpha 2 b$ treatment failure
}

\author{
Ewa Chmielowska ${ }^{1}$, Maciej Studziński², Sebastian Giebel ${ }^{3}$, Anna Krause ${ }^{1}$, Monika Olejniczak ${ }^{1}$, Aleksandra Grzanka ${ }^{4}$ \\ ${ }^{1}$ Clinical Oncology Department, Oncology Center, Bydgoszcz, Poland \\ Head of the Department: Ewa Chmielowska MD, PhD \\ ${ }^{2}$ Clinic of Oncology and Brachytherapy, Nicolaus Copernicus University in Torun, Ludwik Rydygier Collegium Medicum in Bydgoszcz, Poland \\ Head of the Department: Prof. Roman Makarewicz MD, PhD \\ ${ }^{3}$ Department of Bone Marrow Transplantation and Hematooncology, Nicolaus Copernicus University in Torun, Ludwik Rydygier \\ Collegium Medicum in Bydgoszcz, Poland \\ Head of the Department: Prof. Sebastian Giebel \\ ${ }^{4}$ Department of Dermatology, Univeristy Hosptal No. 1, Bydgoszcz, Poland \\ Head of the Department: Rafal Czajkowski MD, PhD
}

Postep Derm Alergol 2015; XXXII, 2: 67-72 DOI: $10.5114 /$ pdia.2014.40941

\begin{abstract}
Introduction: Treatment of T cell cutaneous lymphoma( $\mathrm{CTCL})$ is a controversial subject and the effectiveness of treatment is still low.

Aim: Report of single center experience of management CTCL after progression after first line treatment.

Material and methods: We present 41 patients with CTCL, 29 received interferon $\alpha 2 b$ in first line, and 12 of them received second line therapy.

Results: Overall response rate for second line therapy was $60 \%$.

Conclusions: Results of the follow-up of patients with mycosis fungoides after interferon $\alpha 2 b$ treatment failure with the literature review and discussion.
\end{abstract}

Key words: mycosis fungoides, interferon, chemotherapy.

\section{Introduction}

Treatment of T-cell lymphomas is a controversial subject as there is no established effective treatment and the results of the standard CHOP (cycloposphamide, oncovin, doxorubicin, prednisone)-like chemotherapy are unsatisfactory, especially with regard to the progress that has been made in the treatment of B-cell lymphomas in recent years since the introduction of rituximab [1].

There is no consensus either regarding standard therapy for primary cutaneous T-cell lymphomas. It is a group of rare conditions with a small number of reports on the methods of treatment, especially after the failure of local therapy. Knowledge of this topic is limited due to the lack of major studies on this issue.

Until recently, the number of drugs dedicated to the treatment of these disorders was very limited and irrespective of the treatment line consisted of the same options. Treatment of mycosis fungoides (MF) consisted primarily of psoralen phototherapy (PUVA)-therapy [2, 3], total skin electron beam radiation therapy for stages I-III [4-6] and extracorporeal photopheresis when Sezary's syndrome (SS) developed [7, 8].

Interferon $\alpha 2 b$ is still a well-established first-line systemic treatment option [9-11]. Subsequent treatment lines include bexarotene [12-15], cytotoxic agents such as low dose methotrexate $[9,16,17]$, liposomal doxorubicin or gemcitabine $[18,19]$. Multidrug regimens are not recommended due to the increased risk of infectious events in this group of patients with extensive skin barrier damage.

It is worth mentioning that most recommendations are based on experts' opinions and consensus rather than data from clinical trials [20-22]. ESMO guidelines for primary cutaneous lymphomas recommend PUVA-therapy combined with interferon or bexarotene in patients who failed to respond to local therapy mo-

Address for correspondence: Ewa Chmielowska MD, PhD, Clinical Oncology Department, Oncology Center, 2 Romanowskiej St, 85-796 Bydgoszcz, Poland, phone: +48 5237434 17, fax: +48 5237434 17, e-mail: ewacelin@poczta.wprost.pl Received: 9.08.2013, accepted: 28.10.2013. 
dalities. In cases of further disease progression, usage of gemcitabine, liposomal doxorubicin or histone deacetylase inhibitors (HDAC) inhibitors is suggested [20, 23]. For young patients, allogeneic hematopoietic stem cell transplantation is an option; there is no standard method of conditioning the regimen that should be applied. For SS, extracorporeal photopheresis is recommended with the expected rate of partial responses of $30-80 \%$ and 14-25\% of complete remissions. Similar recommendations were published by the Polish Lymphoma Research Group [20, 23].

Recently a number of novel agents have been developed. Histone deacetylase inhibitors are potent drugs both in MF and SS. There are currently four drugs in this group - vorinostat, romidepsin [24, 25], panobinostat [26] and belinostat [27-29]. Vorinostat (Zolinza) and romidepsin (Istodax) were first to be registered by the Food and Drug Administration (FDA) in the treatment of the refractory and recurrent form of MF/SS [24]. Other drugs are currently subject of research in numerous conditions other than T-cell lymphomas, like Hodgkin's lymphoma or multiple myeloma. The European Medicines Agency (EMA) has not yet registered any of those agents.

The investigated agents include zanolimumab ( $\mathrm{Hu}$ Max-CD4), a fully humanized anti-CD4 antibody. Zanolimumab produces an objective response rate as high as $50 \%$ and the risk of secondary infections, including cytomegalovirus reactivation, is lower than in the case of alemtuzumab [30].

Another novel drug is pralatrexate - antifolate, methotrexate analog, that interferes with dihydrofolate reductase and subsequently leads to cell death. Based on the results of the PROPEL study, it was approved by the FDA in 2009 for patients with relapsed or refractory PTCL. Pralatrexate has not been approved by the EMA [31, 32].

Ongoing clinical trials investigate other novel agents - retinoids like tazarotene, antiangiogenic drugs - lenalidomide (Revlimid) [33], selective immunosuppressive agent for T-cells-Forodesine (BCX-1777) [34], synthetic oligonucleotides and toll-like receptor antagonists [35].

Known agents like temozolomide, oral derivative of dacarbazine, are also being investigated - in the phase II trial conducted on 26 patients, overall response rate (ORR) was 27\% with overall survival 24 months [36, 37]. Another novel agent is C-Beta kinase inhibitor - enzastaurin; 25 patients were recruited in the clinical trial and benefited from treatment mainly in the form of relief of itching; progression-free survival was 78 days [38].

The object of the studies is also immunotoxins - denileukin diffitox, diphtheria toxin and interleukin-2 conjugate, already approved by the FDA [39]. In the phase III placebo-controlled trial on 144 patients, ORR was 44\%, including $10 \%$ of complete remissions and $34 \%$ of partial remissions. The effect was dose-dependent - the group who received a dose of $18 \mathrm{mg} / \mathrm{kg} /$ day had ORR of $49 \%$ compared to $34 \%$ ORR in a group who received $9 \mathrm{mg} /$ $\mathrm{kg} /$ day. Progression-free survival was significant - more than 2 years.

There are also attempts to combine novel drugs like denileukin diffitox with bexarotene or HDACs, which in theory should result in an increased number of receptors for interleukin-2 [40].

All those reports give reasons to hope that therapeutic options for this group of patients will expand, which is of up most importance given the chronic course of disease severely impairing quality of life.

\section{Aim}

The aim of this paper is to report a single-center experience of patient management after disease progression after the first line treatment with interferon $\alpha 2 b$.

\section{Material and methods}

Forty-one patients with mycosis fungoides treated in the Oncology Center in Bydgoszcz of whom 29 received interferon $\alpha 2 b$ as the first line of treatment. The stages of disease ranged from IB to III. Their median age was 51 (range: $37-75$ years).

In 12 cases, the disease subsequently progressed after median time of 38 months. In this cohort, 1 to 5 subsequent lines of systemic therapy was introduced.

The $2^{\text {nd }}$ line treatment included chemotherapy alone (gemcitabine, $n=1$ patient) or with concurrent use of interferon (either methotrexate or doxorubicin, $n=7$ patients), bexarotene ( $n=2$ patients), pralatrexate ( $n=1$ patient) or corticosteroid therapy ( $n=1$ patient). The $3^{\text {rd }}$ line of treatment included histone deacetylase inhibitors - romidepsin, vorinostat ( $n=2$ patients), doxorubicin ( $n=1$ patient) and gemcitabine ( $n=3$ patients). The fourth ( $n=4$ patients) and fifth ( $n=3$ patients) line consisted of the same drugs as in the $2^{\text {nd }}$ and $3^{\text {rd }}$ line. One patient received allogeneic hematopoietic cell transplantation (HCT), as a $4^{\text {th }}$ line, from a matched related donor after radiation-based conditioning regimen - total body and total skin irradiation.

To sum up, methotrexate was chosen as a treatment option 5 times, liposomal doxorubicin - 6, gemcitabine -5 , bexarotene -2 , and other drugs were used in individual patients.

Because of the existing differences concerning approved indications and complex reimbursement policies we decided to present a method of obtaining used agents in the form of a Table 1.

\section{Results}

Second-line treatment results - progression-free survival was 5.37 months. The objective response rate was 67\% (complete remission $(C R)=0$; partial remission (PR) $=8$; stabilisation disease $(\mathrm{SD})=3$; progression disease $(P D)=1$. Third-line treatment results - progression free 
survival (PFS) was 6.06 months, $O R R=50 \%(C R=0$, $P R=4, S D=2)$.

Forth-line treatment results (excluding the patient treated with alloHCT) - PFS $=3.6$ months. The probability of the overall survival (OS) at 5 years was $64 \%$. Tables 2 and 3 present detailed treatment information.

The best treatment result was obtained in the patient in whom allogeneic hematopoietic stem cell transplantation was performed - the patient received complete and long-lasting remission - a result not possible to be achieved by chemotherapy. Combined usage of liposomal doxorubicin and interferon prior to the alloHCT procedure resulted in regression of skin lesions and served as induction phase treatment. One of the patients treated with romidepsin was also qualified to the alloHCT procedure, but treatment had to be canceled due to active HBV infection. Both mentioned patients are young people with no other severe comorbidities.

Analyzing the rest of patients, it should be noted that the longest clinical benefit period was observed in 2 patients treated with bexarotene in the second-line treatment (12 and 9 months, respectively).

Each subsequent line of treatment was associated with lower efficacy. Incorporating novel agents into clinical practice was associated with a clear improvement in the efficiency and thus better prognosis.

\section{Discussion}

Primary cutaneous T-cell lymphomas are still an unresolved clinical problem. It is a group of chronic diseases severely impairing quality of life, even in the early stages of the disease. It is therefore always symptomatic disease that requires treatment.
Table 1. Source of the drug access

\begin{tabular}{lc}
\hline Drug name & Method of obtaining \\
\hline Methotrexate & Reimbursement \\
Liposomal/pegylated & $\begin{array}{c}\text { Drug not reimbursed } \\
\text { Request to the national } \\
\text { health provider }\end{array}$ \\
\hline Gemcitabine & $\begin{array}{c}\text { Drug not reimbursed } \\
\text { Request to the national } \\
\text { health provider }\end{array}$ \\
\hline Bexarotene & $\begin{array}{c}\text { Drug not reimbursed } \\
\text { Request to the national } \\
\text { health provider }\end{array}$ \\
\hline Prednisone & $\begin{array}{r}\text { Reimbursement } \\
\text { Pralatrexate }\end{array}$ \\
\hline HDACs: & Clinical trial \\
\hline Romidepsin & Donation \\
\hline Vorinostat & Import \\
\hline
\end{tabular}

There are numerous novel treatment options and even though they are not completely effective, they mark the progress that has been made in caring for that group of patients. Those novel modalities include both systemic agents as well as new radiotherapy techniques.

Clinical and cost-effectiveness analyses of every new modality should take into account that it is a rare disease affecting patients in their productive age and otherwise able to work. Unfortunately, most of publications lack that kind of economic analysis.

In Poland, drugs other than methotrexate that are recommended by the Polish Lymphoma Research Group

Table 2. Detailed treatment plan in particular patients

\begin{tabular}{|c|c|c|c|c|c|c|c|}
\hline $\begin{array}{l}\text { Age } \\
\text { [years] }\end{array}$ & Stage & $\begin{array}{l}1^{\text {st }} \text { line treatment } \\
\text { duration [months] }\end{array}$ & $\begin{array}{c}\text { Best } \\
\text { response }\end{array}$ & $2^{\text {nd }}$ line & $\begin{array}{l}\text { Response } \\
\text { to } 2^{\text {nd }} \text { line }\end{array}$ & $3^{\text {rd }}$ line & $\begin{array}{l}\text { Response } \\
\text { to } 3^{\text {rd }} \text { line }\end{array}$ \\
\hline 65 & III & 38 & PR & Bexarotene & SD & Gemcitabine & SD \\
\hline 55 & III & 3 & SD & INF + MTX & SD & Vorinostat & SD \\
\hline 37 & III & 16 & PR & INF + MTX & SD & DOX & PR \\
\hline 48 & III & 22 & PR & Gemcitabine & PR & Romidepsin & PR \\
\hline 65 & III & 25 & CR & Pralatrexate & PR & & \\
\hline 53 & III & 17 & PR & INF + MTX & PR & & \\
\hline 49 & III & 40 & PR & INF + PRED & PR & & \\
\hline 62 & III & 18 & SD & INF + DOX & PR & & \\
\hline 45 & III & 6 & SD & INF + MTX & PR & & \\
\hline 75 & III & 5 & SD & INF + MTX & PD & & \\
\hline 49 & III & 10 & PR & INF + DOX & PR & INF + GEM & PR \\
\hline 47 & III & 48 & PR & Bexarotene & PR & $I N F+G E M$ & PR \\
\hline
\end{tabular}


Table 3. Detailed treatment plan in particular patients

\begin{tabular}{|c|c|c|c|c|c|c|c|}
\hline $\begin{array}{l}\text { Age } \\
\text { [years] }\end{array}$ & Stage & $\begin{array}{l}1^{\text {st }} \text { line treatment } \\
\text { duration [months] }\end{array}$ & $\begin{array}{c}\text { Best } \\
\text { response }\end{array}$ & $4^{\text {th }}$ line & $\begin{array}{l}\text { Response } \\
\text { to } 4^{\text {th }} \text { line }\end{array}$ & $5^{\text {th }}$ line & $\begin{array}{l}\text { Response } \\
\text { to } 5^{\text {th }} \text { line }\end{array}$ \\
\hline 65 & III & 38 & PR & DOX & SD & MTX & SD \\
\hline 55 & III & 3 & SD & GEM + INF & SD & DOX & SD \\
\hline 37 & III & 16 & PR & alloHCT + TBI + TSI & $C R$ & & \\
\hline 48 & III & 22 & PR & & & & \\
\hline 65 & III & 25 & $C R$ & & & & \\
\hline 53 & III & 17 & $P R$ & RTH & PD & DOX & SD \\
\hline 49 & III & 40 & $P R$ & & & & \\
\hline 62 & III & 18 & SD & & & & \\
\hline 45 & III & 6 & SD & & & & \\
\hline 75 & III & 5 & SD & & & & \\
\hline 49 & III & 10 & $P R$ & & & & \\
\hline 47 & III & 48 & $\mathrm{PR}$ & & & & \\
\hline
\end{tabular}

in second-line treatment are not reimbursed; they can only be used after obtaining special consent of the national health provider [23]. The procedure of requesting for individual reimbursement will no longer be continued and access to drugs like gemcitabine, liposomal doxorubicin or bexarotene will not be possible [41].

Interferon is a valuable treatment option, but the disease inevitably progresses [9-11, 42]. Allogeneic hematopoietic stem cell transplantation is a promising therapeutic modality, but is dedicated to a limited group of young and otherwise healthy patients [43, 44].

Presented results show that good clinical effects can be achieved when relatively aggressive treatment is applied, like alloHCT. Currently there is an ongoing trial by Polish Lymphoma Research Group (PLRG) regarding the value of alloHCT preceded by radiation-based conditioning inpatients whose disease progressed after one systemic treatment line.

Extracorporeal photopheresis is not available in Poland $[7,45,46]$. Access to radiotherapy, both total skin electron beam therapy (TSEB) and helical to motherapy, is limited. It is therefore critical to have access to at least one systemic agent that could be used after interferon treatment failure $[47,48]$.

\section{Conclusions}

Presented results and cited literature indicate that the use of several lines of treatment results in improved quality of life and disease regression that can last for many months. It should be noted that in most cases, initiation of the next line of treatment after failure of the previous one was usually delayed by formal proceedings required to obtain the drug. By the time of approval of novel agents like romidepsin or pralatrexate by the European Medicines Agency (EMA), usage of liposomal doxorubicin or gemcitabine in combination with interferon seems to be a reasonable treatment option especially for patients not eligible for the allotransplantation procedure. Proposed treatment is recommended by PLRG and should be reimbursed by the national health provider.

\section{Conflict of interest}

The authors declare no conflict of interest.

\section{References}

1. Coiffier B, Lepage E, Briere J, et al. CHOP chemotherapy plus rituximab compared with $\mathrm{CHOP}$ alone in elderly patients with diffuse large-B-cell lymphoma. N Engl J Med 2002; 346: 235-42.

2. Trautinger F. Phototherapy of mycosis fungoides. Photodermatol Photoimmunol Photomed 2011; 27: 68-74.

3. Pothiawala SZ, Baldwin BT, Cherpelis BS, et al. The role of maintenance phototherapy in cutaneous T-cell lymphoma. J Drugs Dermatol 2010; 9: 800-3.

4. Yu JB, Khan AM, Jones GW, et al. Patient perspectives regarding the value of total skin electron beam therapy for cutaneous T-cell lymphoma/mycosis fungoides: a pilot study. Am J Clin Oncol 2009; 32: 142-4.

5. Navi D, Riaz N, Levin YS, et al. The Stanford University experience with conventional-dose, total skin electron-beam therapy in the treatment of generalized patch or plaque (T2) and tumor (T3) mycosis fungoides. Arch Dermatol 2011; 147: 561-7.

6. Piotrowski T, Milecki P, Skórska M, Fundowicz D. Total skin electron irradiation techniques: a review. Postep Derm Alergol 2013; 30: 50-5. 
7. Oliven A, Shechter Y. Extracorporeal photopheresis: a review. Blood Rev 2001; 15: 103-8.

8. Wilson LD, Jones GW, Kim D, et al. Experience with total skin electron beam therapy in combination with extracorporeal photopheresis in the management of patients with erythrodermic (T4) mycosis fungoides. J Am Acad Dermatol 2000; 43: 54-60.

9. Rupoli CS, Ospedale E. Low dose interferon $2 b$ combined with PUVA is an effective treatment of early stage mycosis fungoides: results of a multicenter study. Haematologica 1999; 84: 809-13.

10. Ross C, Tingsgaard P, Jørgensen H, Vejlsgaard GL. Interferon treatment of cutaneous T-cell lymphoma. Eur J Haematol 1993; 51: 63-72.

11. Dreno B, Godefroy WY, Fleischmann M, et al. Low-dose recombinant interferon-alpha in the treatment of cutaneous T-cell lympbomas. Br J Dermatol 1989; 121: 543-4.

12. Talpur R, Ward S, Apisarnthanarax N, et al. Optimizing bexarotene therapy for cutaneous T-cell lymphoma. J Am Acad Dermatol 2002; 47: 672-84.

13. Duvic M, Hymes K, Heald P, et al. Bexarotene is effective and safe for treatment of refractory advanced-stage cutaneous T-cell lymphoma: multinational phase II-III trial results. J Clin Oncol 2001; 19: 2456-71.

14. Duvic M, Martin AG, Kim Y, et al. Phase 2 and 3 clinical trial of oral bexarotene (Targretin capsules) for the treatment of refractory or persistent early-stage cutaneous T-cell lymphoma. Arch Dermatol 2001; 137: 581-93.

15. Sokołowska-Wojdyło M, Ługowska-Umer H, Maciejewska-Radomska A. Oral retinoids and rexinoids in cutaneous T-cell lymphomas. Postep Derm Alergol 2013; 30: 19-29.

16. Berger E, Altiner A, Chu J, et al. Mycosis fungoides stage IB progressing to cutaneous tumors. Dermatol Online J 2011; 17: 5.

17. Avilés A, Nambo MJ, Neri N, et al. Interferon and low dose methotrexate improve outcome in refractory mycosis fungoides/Sézary syndrome. Cancer Biother Radiopharmaceut 2007; 22: 836-40.

18. Zinzani PL, Baliva G, Magagnoli M, et al. Gemcitabine treatment in pretreated cutaneous T-cell lymphoma: experience in 44 patients. J Clin Oncol 2000; 18: 2603-6.

19. Duvic M, Talpur R, Wen S, et al. Phase II evaluation of gemcitabine monotherapy for cutaneous T-cell lymphoma. Clin Lymph Myeloma 2006; 7: 51-8.

20. Willemze R, Dreyling M. Primary cutaneous lymphomas: ESMO Clinical Practice Guidelines for diagnosis, treatment and follow-up. Ann Oncol 2010; 21 Suppl 5: v177-80.

21. Prince HM, Whittaker S, Hoppe RT. How I treat mycosis fungoides and Sézary syndrome. Blood 2009; 114: 4337-53.

22. Willemze R, Dreyling M, Dummer R. Primary cutaneous lymphoma: ESMO clinical recommendations for diagnosis, treatment and follow-up. Ann Oncol 2008; 19 Suppl 2: ii72-6.

23. Sokołowska-Wojdyło M, Lech-Marańda E, Placek W, et al. Leczenie pierwotnych chłoniaków skóry. Rekomendacje Sekcji Chłoniaków Skóry Polskiej Grupy Badawczej Chłoniaków (PLRG). Onkologia w Praktyce Klinicznej 2010; 6: 29-47.

24. Whittaker SJ, Demierre MF, Kim EJ, et al. Final results from a multicenter, international, pivotal study of romidepsin in refractory cutaneous T-cell lymphoma. J Clin Oncol 2010; 28: 4485-91.

25. Piekarz RL, Frye R, Turner M, et al. Phase II multi-institutional trial of the histone deacetylase inhibitor romidepsin as monotherapy for patients with cutaneous T-cell lymphoma. J Clin Oncol 2009; 27: 5410-7.
26. Ellis L, Pan Y, Smyth GK, et al. Histone deacetylase inhibitor panobinostat induces clinical responses with associated alterations in gene expression profiles in cutaneous T-cell lymphoma. Clin Cancer Res 2008; 14: 4500-10.

27. Gimsing P. Belinostat: a new broad acting antineoplastic histone deacetylase inhibitor. Expert Opin Investig Drugs 2009; 18: 501-8.

28. Kavanaugh SM, Kavanaugh SA, White LA, Kolesar JM. Vorinostat: a novel therapy for the treatment of cutaneous T-cell lymphoma. Am J Health System Pharm AJHP2010; 67: 793-7.

29. Duvic M, Vu J. Vorinostat: a new oral histone deacetylase inhibitor approved for cutaneous T-cell lymphoma. Expert Opin Investig Drugs 2007; 16: 1111-20.

30. d'Amore F, Radford J, Relander T, et al. Phase II trial of zanolimumab (HuMax-CD4) in relapsed or refractory non-cutaneous peripheral T cell lymphoma. Br J Haematol 2010; 150: 565-73.

31. O'Connor OA, Pro B, Pinter-Brown L, et al. Pralatrexate in patients with relapsed or refractory peripheral T-cell lymphoma: results from the pivotal PROPEL study. J Clin Oncol 2011; 29: 1182-9.

32. Foss F, Horwitz SM, Coiffier B, et al. Pralatrexate is an effective treatment for relapsed or refractory transformed mycosis fungoides: a subgroup efficacy analysis from the PROPEL study. Clin Lymph Myeloma Leuk 2012; 12: 238-43.

33. Querfeld CRS, Kuzel TM, Guitart J, Querfeld CKT. Preliminary results of a phase II study of CC-5013 (Lenalidomide, RevlimidTM) in patients with cutaneous T-cell lymphoma. Blood 2005; 106: 936-7.

34. Madeleine Duvic YKM, Forero-Torres A, Foss F, et al. Response to oral forodesine in refractory cutaneous T-cell lymphoma: interim results of a phase I/II study. Oncology 2007; Suppl. 1.

35. Kim YH, Girardi M, Duvic M, et al. Phase I trial of a Toll-like receptor 9 agonist, PF-3512676 (CPG 7909), in patients with treatment-refractory, cutaneous T-cell lymphoma. J Am Acad Dermatol 2010; 63: 975-83.

36. Tani M, Fina M, Alinari L, et al. Phase II trial of temozolomide in patients with pretreated cutaneous T-cell lymphoma. Haematologica 2005; 90: 1283-4.

37. Querfeld C, Rosen ST, Guitart J, et al. Multicenter phase II trial of temozolomide in mycosis fungoides/sezary syndrome: correlation with 06-methylguanine-DNA methyltransferase and mismatch repair proteins. Clin Cancer Res 2011; 17: 5748-54.

38. Querfeld C, Kuzel TM, Kim YH, et al. Multicenter phase II trial of enzastaurin in patients with relapsed or refractory advanced cutaneous T-cell lymphoma. Leuk Lymph 2011; 52: 1474-80.

39. Prince HM, Duvic M, Martin A, et al. Phase III placebo-controlled trial of denileukin diftitox for patients with cutaneous T-cell lymphoma. J Clin Oncol 2010; 28: 1870-7.

40. Cervigón-González I, Torres-Iglesias LM, Palomo-Arellano A, Gil-Pascual B. Advanced-stage primary cutaneous T-cell lymphoma treated with bexarotene and denileukin diftitox. Case Rep Dermatol 2011; 3: 13-7.

41. Decision 45/13/2009 about reimbursement of Targretin in Poland in CTCL. Agency for Health Technology Assessment. Agencja Oceny Technologii Medycznych 2009.

42. Chmielowska E, Grzanka A, Krause A, et al. Clinical benefit and safety of interferon alfa $2 b$ (INF) in therapy of mycosis fungoides. Onkologia w Praktyce Klinicznej 2011; 7: 301-10.

43. Duarte RF, Canals C, Onida F, et al. Allogeneic hematopoietic cell transplantation for patients with mycosis fungoides and Sézary syndrome: a retrospective analysis of the Lymphoma 
Working Party of the European Group for Blood and Marrow Transplantation. J Clin Oncol 2010; 28: 4492-9.

44. Duarte RF, Schmitz N, Servitje O, Sureda A. Haematopoietic stem cell transplantation for patients with primary cutaneous T-cell lymphoma. Bone Marrow Transplant 2008; 41: 597-604.

45. Arulogun S, Prince HM, Gambell P, et al. Extracorporeal photopheresis for the treatment of Sézary syndrome using a novel treatment protocol. J Am Acad Dermatol 2008; 59: 589-95.

46. Bisaccia E, Vonderheid EC, Geskin L. Safety of a new, single, integrated, closed photopheresis system in patients with cutaneous T-cell lymphoma. Br I Dermatol 2009; 161: 167-9.

47. Welsh JS, Patel RR, Ritter MA, et al. Helical tomotherapy: an innovative technology and approach to radiation therapy. Technol Cancer Res Treat 2002; 1: 311-6.

48. Jeraj R, Mackie TR, Balog J, et al. Radiation characteristics of helical tomotherapy. Med Phys 2004; 31: 396-404. 